\title{
Development of Teaching Material Market Place Activity (Mpa) Engineering Based On Character Values In Learning Student Class V SD Sudirman 1 Makassar City
}

\author{
Andi Makkasau ${ }^{1}$, Lutfi $B^{2}$, and Nuraeni ${ }^{3}$ \\ \{makkasau@gmail.com $\left.{ }^{1}\right\}$ \\ ${ }^{1,2,3}$ Faculty of Education, Makassar State University Vocational High School 5 Makassar, \\ Indonesia
}

\begin{abstract}
This study aims to produce science-based teaching materials based on character values by applying Market Place Activity (MPA) techniques that are valid, practical and effective. This type of research is the development (research and development) through several stages, namely (1) gathering initial information, (2) design, (3) development, (4) assessment, (5) product revision, and subsequently obtained prototype of science teaching materials. The assessment conducted on the products of natural science teaching materials is the text of natural science teaching materials based on character values using Market Place Activity (MPA) techniques, guidebooks, and LKPD. The assessment of the resulting product is carried out through three stages, namely the assessment of reliability, practicality, and effectiveness. The subjects of the field trials were teachers and fifth grade students at SD Sudirman 1 Makassar City. Data collection was done through questionnaire validation of teaching materials, teacher responses questionnaire, student response questionnaire, interview guide, and learning achievement test. Data analysis was performed through validity analysis and practicality analysis using descriptive analysis. The results of the study showed that: the value of science teaching materials based on character values based on the K-13 curriculum, guidebooks, and worksheets fulfilled the established criteria, namely: valid, practical, and effective so that they were "feasible" to be implemented in the learning process in class. V SD.
\end{abstract}

Keywords: Market Place Activity Techniques, Science teaching materials, Character Values.

\section{Preliminary}

Primary school teachers must be able to provide attention and service in a professional manner so that students can grow and develop in accordance with the potential available to them. The learning process in elementary schools requires a real understanding of teachers, not only from the aspects of professional competence and pedagogical competencies related to basic competencies, but also the character values that need to be instilled in every elementary student. If during this period students experience obstacles caused by inadequate teacher services, then it can be an obstacle for elementary students to advance to compete with other 
students. The mistake of instilling the concept from the beginning, will adversely affect the achievement of results for students.

Elementary school students are unstable figures who continue to develop along with the level of maturity and environmental situations. Learners need new issues related to their way of life as children. Although rationally the teacher knows that the learning process must be related to the environment of students, but the teacher still collides at the stage of developing teaching materials that require an understanding of the analysis of basic competencies. In addition, with a scientific and thematic approach the majority of teachers in elementary schools actually become obstacles in learning practices.

Changes in learning systems, especially in elementary schools as a result of curriculum changes, pose new problems for teachers as the front guard in the field of education. The teacher teaches based on self-arranged lesson schedules. This way of teaching has become a teacher's habit so that when faced with teaching with a new approach often experiences difficulties including; (1) it is difficult to find an easier way to achieve cohesiveness between subjects or between KDs, (2) it is difficult to find links between concepts that can connect two or three basic competencies with different subjects, and (3) it is difficult to apply teaching methods that are can maintain the system of approaches used throughout the learning process. As a result, the only escape from the teacher in teaching is to follow the existing textbooks.

The enactment of the 2013 curriculum requires elementary school teachers to apply innovative learning models or techniques using a scientific approach to learning. Learning with a scientific approach requires the creativity of a teacher to mix and develop teaching materials in an effort to integrate subjects or basic competencies from each theme, sub-theme, and each learning that will be taught in every class, especially the fifth grade of elementary school in each semester according to the learning techniques will be used.

Government Regulation No. 19 of 2005 Article 20 emphasizes that teachers are expected to develop their own learning materials. The ability of teachers to develop and create teaching materials will inspire students to appear more creative in learning. The inability of a teacher to develop teaching materials in learning is noteworthy especially by the city education office. Teachers who use teaching materials to rely solely on the availability of textbooks are not sufficient to be able to meet professional and pedagogical competencies in learning. Teaching materials in textbooks, especially in class $\mathrm{V}$, are minimal materials that still need to be developed according to the conditions of students and their environment.

The curiosity of teachers to compile their own teaching materials is sometimes poisoned by textbooks that are lost in the cognitive realm only. The offer of inferior quality textbook shortcuts by many publishers has also turned off the creativity of teachers, and eventually teachers fall prey to the book business market. The teacher again becomes consumptive as "the preacher of the contents of a textbook that is labeled according to the applicable curriculum".

The reality in the field shows, the ability of teachers to understand the scientific approach by applying various models and learning techniques based on character values according to the demands of the 2013 curriculum has been snatched up by teacher and student books labeled thematically whose contents are still far from thematic philosophies and learning techniques that are used. Even the application of the learning model is still very limited to the four suggested models namely the Base Learning Project, PBL, Discovry Learning and inquiry learning. In this case there are still many models and other learning techniques that should be used.

Various efforts that have been carried out by the government so that teachers are able to develop teaching materials, especially grade $\mathrm{V}$ elementary school, include training large numbers of teachers in the form of activities that are commonly carried out in the hope that the 
change targets can be realized in large numbers as well. In addition, funds sourced from BOS (School Operational Assistance) are also large enough to finance the improvement of teacher professionalism. Ideally, with these resources and funds, the teacher has been able to develop teaching materials well especially the substance of class $\mathrm{V}$ teaching materials is fairly simple. However, the ability of teachers in these fields has not shown any change in line with expectations. In general, teachers still maintain textual teaching methods, not contextual as expected by the applicable curriculum.

Teaching materials or teaching materials are basically a set of materials that are deliberately arranged systematically which allows the creation of conditions for students to learn. Sudrajat (2008) states teaching materials are a set of materials that are arranged systematically both written and unwritten so as to create an environment or atmosphere that allows students to learn. One of the initial activities in improving learning is designing teaching materials that refer to a development model to facilitate learning (Degeng, 1989). The design of teaching materials is the foundation for improving the quality of learning. Teaching material contains aspects of behavior expected by a student after going through learning activities. Dick and Carey (1990) stated the development of learning materials as one component of the learning system that cannot be separated from other learning components.

In this study, values-based teaching materials are interpreted as a way of thinking and acting to develop teaching materials in grade $\mathrm{V}$ elementary school that are grounded in praiseworthy moral values such as honesty, tolerance, cooperation, discipline, mutual respect, frugal life, and responsibility. When a teacher develops teaching materials must explicitly contain one or several moral values that will be familiarized by students both while in the school environment, and outside the school. Every curriculum that applies, must contain the principle of balance between the cognitive, affective and psychomotor domains. The problem then arises when the teacher implements the lesson plan in the learning process, usually the teacher only focuses on the cognitive aspects of following the material or material of the textbook and does not pay attention to the moral aspects. This phenomenon is caused by the conventional paradigm which views the achievement of learning outcomes as evident in the high or low student acquisition scores after being tested both in writing and orally. By using the Market Place Activity (MPA) technique in character-based learning in character values in developing teaching materials for fifth grade elementary school students the phenomenon can be minimized.

One of the creative efforts that can be made for teachers to make it easier to apply a scientific approach in the development of teaching materials, especially in class V SD is the Market Place Activity (MPA) technique, this technique will encourage and challenge teachers to strive to continue to develop teaching materials according to their content and context . Reigeluth (1992) suggests that the design of teaching materials should modify one of the standard techniques (standard blue prints) that best suits the special needs of learning. A learning technique or teaching material can be an inspiration for someone to design a new technique in accordance with the characteristics of the subject and students. In this study, researchers will create a Market Place Activity (MPA) technique that has been used in science learning concepts in the 2006 and 2013 curriculum to become one of the techniques for developing grade $\mathrm{V}$ science teaching materials called the Market Place Activity (MPA) technique in value-based science learning character. 


\section{Research Methods}

This research is a type of development research that uses the Borg \& Gall procedural model. The procedural model is a descriptive model that uses procedural steps or steps that must be followed to produce certain products (Setyosari 2010). This study aims to produce science-based class V natural science teaching materials based on Market Place Activity (MPA) techniques. This research was designed using the Borg \& Gall (2003) procedural model. namely (1) gathering initial information, (2) planning, (3) developing the initial product format, (4) initial testing, (5) product revision, and (6) Prototype of science teaching materials. With this procedure, finally it produces a character-based science teaching product based on character values with valid, practical and effective Market Place Activity (MPA) techniques. Product testing subjects: (1) content experts in the fields of study and learning design, (2) teachers, and (3) students. Field trials are conducted at SD Sudirman 1 accredited A. For data collection, they are used: (1) observation sheets, (2) questionnaires, (3) interview guidelines, (4) learning outcomes tests, and (5) documentation analysis. The data collected was analyzed descriptively. As a basis for decision making criteria used are very good, good, enough, less, and not good.

\section{Results And Discussion}

The results of the research described below are (1) a description of the need for developing teaching materials; (2) expert responses to teaching material products and supporting devices; and (3) teacher responses to teaching material products; and (4) student responses to the use of teaching materials. For details, it can be described as follows.

1. Description of the Need for Development of Teaching Materials

This needs analysis activity is carried out with the aim of identifying the need to develop teaching materials and tools for fifth grade students using Market Place Activity (MPA). There are four activities carried out at this stage, namely: (a) conducting a field survey of the implementation of character-based learning in schools, (b) identifying lesson themes through the study of curriculum content, (b) interviews with implementing parties in primary school learning, and (c) review character values.

The results of the initial survey and interviews with the fifth grade teacher and a policy maker (school principal) on the implementation of education indicate that character-based learning has been running from grade 1 to grade 6 , but it has not proceeded as it should. The results of interviews with class V teachers and principals conducted on Friday 05 July 2019 showed that character-based learning has been running from grade 1 to grade 6 , but still has problems because there are no structured instructional materials available that can be used by teachers in implementing learning, especially science learning based on praiseworthy values for students in elementary school.

The nine MPA themes are broken down into a number of subject matter and sub-subject matter for the development of teaching materials with Market Place Activity techniques for fifth grade elementary school students. The topics consist of supporting topics and value-based topics. Each topic in the arrangement is left up to the teacher according to the depth, breadth of material content, student abilities, and learning resources / media available at school. The selection and arrangement of MPA topics should be based on the principle of learning from easy to difficult, from close to the child to far from the child, from simple to complex, and from the concrete to the abstract so that the learning experience of students can be more meaningful. Meaningful learning experiences will build praiseworthy character, encourage 
mastery of concepts, enhance high-level scientific thinking skills, enhance the ability to solve problems, and build creativity.

2. Expert Responses to Teaching Material Products and equipment

The teaching material produced is based on 9 themes for fifth grade elementary school students according to the results of the needs analysis. Product teaching materials are arranged based on the theme level, namely MPA teaching material theme 1; MPA teaching materials theme 2, and so on until MPA theme teaching materials 9.

To produce teaching materials and supporting devices that are valid and practical have also been produced teaching instrument validation instruments, manuals and worksheets, as well as limited testing instruments for the target user. The product is then validated by the content expert in the field of study and learning design expert. Validation testing aims to assess the quality of the content and construct of teaching materials and tools through responses, criticisms and suggestions for product improvement from content experts and learning design. As an evaluation criteria using a scale of $0-4$ (very good, good, enough, less, and not very good).

a. Teaching Material Validation Results

Teaching material products that have been produced are assessed by 1 content expert, 1 grade $\mathrm{V}$ teacher, and 1 curriculum and Education technology expert. A class V expert and teacher gives an assessment of the appropriateness of content, presentation, linguistic, and graphic skills. Based on the results of the assessment of the validator and the subject guide showed that the textbooks produced were 3.64. When consulted with the criteria are in the category of "very good". This means that the teaching material product has quality content and is worthy of being passed on in field trials to the research target. For more details about the results of the validation of teaching material products can be seen in the following table 1:

Table 1. Textbook Validation Results

\begin{tabular}{llcl}
\hline No & \multicolumn{1}{c}{ Component } & Average Rating & category \\
\hline 1 & Feasibility of structure & 3,60 & Very valid \\
2 & Content eligibility & 3,60 & Very valid \\
3 & Feasibility of presentation & 3,80 & Very valid \\
& Language Feasibility & & \\
4 & The feasibility of a graphic & 3,70 & Very valid \\
5 & & 3,50 & Very valid \\
& & & \\
\hline & Average & $\mathbf{3 , 6 4}$ & Very Valid \\
\hline
\end{tabular}

In table 1 Textbooks that are developed are categorized as "very valid". The indications for assessment in the student book consist of the feasibility of a "structure", which includes: systematic, rationalization, material updates, encouraging curiosity, and not nuanced in the way of moral values. The appropriateness of the contents with indications: conceptual understanding, material accuracy, material up-to-date, encouraging curiosity, and not nuanced in deviation of moral values. Appropriateness of presentation with indications: encourages the active involvement of students, interrelationship between sections, cohesiveness between divisions, harmony between concepts, presentation in contextual terms. Language eligibility with indications: legibility, clarity of information, compliance with Indonesian language rules, and the use of language effectively and efficiently. Feasibility of graphics with indications: 
layout, layout and illustration. Each of these sub-aspects meets the eligibility criteria and makes it easy for the target user.

a. Handbook Validation Results

To assess the appropriateness of the teacher's manual, the validator provides an assessment of four aspects, namely: the appropriateness of the content, the appropriateness of the presentation, the appropriateness of the language, and the appropriateness of the graphic. Based on the validation of experts and grade $\mathrm{V}$ elementary school teachers, the resulting manuals are categorized as "very valid". Details of student teacher validation results are presented in table 2 below:

Table 2: Validation Results of the Guidebook

\begin{tabular}{llcc}
\hline No & Aspect & Average Rating & Category \\
\hline 1 & Content eligibility & 3,70 & Very Valid \\
2 & Feasibility of presentation & 3,60 & Very Valid \\
& Language Feasibility & & \\
3 & Feasibility worthiness & 3,70 & Very Valid \\
4 & & 3,60 & Valid \\
\hline & Average & $\mathbf{3 , 6 5}$ & Very Valid \\
\hline
\end{tabular}

Table 2 shows that the manual meets the demands of potential users. Indications for the appropriateness of the contents include: material oriented to the student's book, adequate material to guide the teacher in delivering the material, the accuracy of the material, the stages of learning encourage to develop commendable values and use of media clearly. Feasibility of presentation with indications: wrinkles, systematic, easy to understand; material does not impose moral perversion; interrelationships between sections, sub-sections, and concepts, coherent learning stages; material stages are clear and can be applied with a clear systematic. Feasibility of the language with an indication: using standard language, easy to understand and the accuracy of the use of the term. Feasibility of graphics with indications: layout, layout and interesting variations. Each of these indications fulfills the criteria so that it is suitable for use in the research objectives.

a. Product Validation Results for Student Activity Sheets

To assess the feasibility of the Student Worksheet (LKS) the validator provides an assessment of aspects consisting of: the appropriateness of content, language, presentation, and graphics. Based on the results of expert and practical validations, the worksheets developed were categorized as "very valid". Details of student teacher validation results are presented in table 3 below:

Table 3: Validation Results for Student Activity Sheets

\begin{tabular}{llcc}
\hline No & Component & Average Rating & Category \\
\hline 1 & Content eligibility & 3,73 & Very Valid \\
2 & Linguistic & 3,67 & Very Valid \\
3 & Serving & 3,73 & Very Valid \\
4 & Grapefruit & 3,67 & Valid \\
\cline { 2 - 4 } & Average & $\mathbf{3 , 7 0}$ & Very Valid \\
\hline
\end{tabular}


Table 3 shows that the worksheets developed are categorized as "very valid". The experts provide an assessment of the appropriateness of content, the appropriateness of the language, the appropriateness of the presentation, and the appropriateness of graphics with the category "very good". As an indication of the appropriateness of the contents, it contains about: conformity with KI and KD, compatibility with the needs of students; conformity with teaching materials, the truth of the substance of the material, usefulness, and conformity with the praiseworthy value for children. Indications of the appropriateness of the presentation, namely: clarity of purpose, order of presentation, motivation, interactivity, and completeness of information. Indications of language eligibility, namely: readability, clarity of information, conformity to standard Indonesian language rules, and effective use of language. Indicative feasibility of graphics, namely: the use of type and size of letters, layout, layout, graphics, and display design.

d. Teacher responses to product development

The teacher's response to the product is carried out with the aim of obtaining responses, criticism and teacher evaluations of the prototype of teaching materials, manuals, and worksheets.

Teaching material products, guidebooks, and student worksheets that have been approved by experts, must be tested in the field for prospective users, namely grade 5 elementary school teachers. The aim is to describe the prospective user's responses to the product before use. Ideally, field testing of a product should be done individually, limited and expanded (Puslitjaknow 2008). In this research study the study focused on limited testing. Limited testing intends to obtain responses, criticisms, assessments, and suggestions for improvement and adjustment of teaching material products that are developed. This test is carried out to determine the "practicality" of the product according to established criteria. The final result expected in this test is whether the product produced is suitable and makes it easy for potential users to use it.

The teacher's response to the three products was given limited to 3 teachers, with details of grade 4, 5, and 6 teachers each of 1 teacher. Teacher response data on limited testing is quantitative and qualitative. Quantitative data, namely data chosen by the teacher based on alternative answers provided in the teacher's questionnaire responses. Qualitative data is data obtained by filling in the space provided in the form of suggestions for product improvement / revision. The results of quantitative analysis of teacher responses to the three products are described in table 4 below.

Table 4. Results of Teacher Responses to Development Products

\begin{tabular}{llcc}
\hline No & \multicolumn{1}{c}{ Component } & Average Rating & Category \\
\hline 1 & Teaching materials & 3,80 & Very good \\
2 & Guidebook & 3,60 & Very good \\
3 & LKS & 3,60 & Very good \\
\hline & & & \\
\hline & Average & $\mathbf{3 , 6 7}$ & Very good \\
\hline
\end{tabular}

Thus the three products that have been approved by experts and have been adjusted to the needs of teachers 


\section{DISCUSSION OF RESEARCH RESULTS}

There are three products that are tested, namely the validity of teaching materials, the validity of the guidebook, and the validity of the worksheet. The results of the analysis of aspects of the product produced have been approved by experts. Qualification of the assessment of aspects of the product is in the category of "very good". The process of determining the legitimacy of the product, following the view of Borg \& Gall (1983) states that the results of the assessment by experts may be used as a principle to determine the validity of a product.

The validity of the product development is carried out by following the Borg \& Gall (2003) model, namely conducting needs analysis, planning, developing, and testing products, and finally giving birth to the finalization of teaching material products. According to Marxt \& Hacklin (2005) Testing the validity of curriculum products by following the predetermined steps is a case that is achieved before its use.

This learning technique some experts say windows shoping (window shopping). For naming, it depends on who gives the name that is theoretically reviewed, but in essence how learning takes place in class such as market activities where there are goods being traded, there are sellers and there are buyers and there are communication media in the form of messages, questions and answers, maintain and even promote a concept or product. Technically, a concept or work will use MPA, so in the study group of students each group is agreed on the division of tasks there is a sales group to promote and maintain the work of the group, there is a function as a buyer of information to go around visiting the work of other groups, good dialogue, questions and answers even evaluate and criticize.

Information traded in each group is the material learned on that day, how students understand the concepts and work in each group by looking for sources of information carried out by group discussions, then poured into a concept work or media that will be easily understood by the students. prospective buyers who will visit the group

This learning technique with MPA contains a nurturant effect in direct character formation, such as being responsible for making work and maintaining his work, working in groups, being open to buyer criticism, working hard to be the best, accustomed to evaluating and evaluating, building independence, self-confidence, group skills, receive feedback, and train responsible for making the best planning and design, as well as many values (valuing) stored in the learning.

Efforts to produce teaching materials with MPA techniques in science learning are expected to be made by students to determine teaching materials that are interconnected and integrate with each other. The teaching materials and equipment products are expected to be used by teachers and students as a guide for implementing learning in the fifth grade of elementary school.

\section{Conclusion}

Based on the results of data analysis shows that the product of science teaching materials based on character values with Market Place Activity techniques, guidebooks, and worksheets is "valid and practical". Means "feasible" to be used in fifth grade elementary school students. This shows that the product of science teaching materials is based on character values according to the characteristics and needs of prospective users. The results of the research development of teaching materials for fifth grade elementary school students contained 9 themes with details (a) MPA 1 with the themes: animal and human motion organs; (b) MPA 2 
with the theme clean air for health; (c) MPA 3 with the theme: healthy food; (d) MPA 4 with the theme: healthy is important; (e) MPA 5 with the theme: ecosystem; (e) MPA 6 with the theme: heat and displacement; (f) MPA 7 with the theme: life events (g) MPA 8 with the theme: our best friend's environment; (9) MPA 9 with the theme: objects around us.

The results of this study are expected to meet the demands of the provision of grade $\mathrm{V}$ science teaching materials based on character values for the learning needs of elementary school students, and at the same time as one of the efforts to present a model of developing innovative teaching materials that can provide academic contributions to improve the practice of virtue values in among students in elementary school.

\section{Refference}

Abdul Madjid dan Andayani, D. 2011. Pendidikan karakter perspektif Islam. Bandung: Remaja rosdakarya.

Borg, W.R. \& Gall, M.D. 1983. Educational Research: an introduction. (third ed.) New York: David McKay.

BSNP. 2006. Panduan Kurikulum Tingkat Satuan Pendidikan. Jakarta: BSNP.

Degeng, I.N.S. 1989. Pengaruh Penstrukturan Isi Teks Ajar dan Strategi Belajar terhadap Perolehan Belajar Mengingat Fakta dan Memahami Konsep. Forum Penelitian Pendidikan, 6 (1): 74-91.

Gall, J. Borg W., \& Gall, M. 2003. Educational research: An introduction (7th ed.) Boston: Pearson Education.

Hernowo. (2003). Quantum Writing: Cara Cepat nan Bermanfaat untuk Merangsang Munculnya Potensi Menulis. Bandung: MLC.

Jensen, Eric \& Karen Makowitz. 2002. Otak Sejuta Gygabite: Buku Pintar Membangun Ingatan Super. Kaifa: Bandung.

Jensen. Eric dan Karen Makowitz. 2002. Otak Sejuta Gygabite: Buku Pintar Membangun Ingatan Super. Kaifa: Bandung.

Kemendikbud. 2013. Pedoman Pelatihan Implementasi Kurikulum 2013. Jakarta: Pusbang Tendik.

Lee, H.N \& Atkinson, J.C. 2006. Character Education. North Corolina: Public Schools. Department of Public Instruction.

Lickona, T. 1992. Educating for character, how our schools can teach respect and responsibility. Bantam books, New York.

Lickona, T. 1994, Raising good children: From birth through the teenage years. New York. Bantam books.

Porter. De Bobbi dan Hernacki. 2008. Quantum Learning: Membiasakan Belajar Nyaman dan Menyenangkan. Kaifa: Bandung.

Marxt, C. \& Hacklin, F. 2005. Design, Product Development, Innovation: all the same in the end? Ashort discussion on terminology. Journal f Engineering Design.

Reigeluth, Charles M. Instructional Design Strategies and Tacties. Educational Technology Publications. New Jersey: Englewood Cliffs.

Republik Indonesia. 2005. Peraturan Pemerintah RI, Nomor 19 tahun 2005 tentang standar nasional pendidikan. Jakarta: Depdiknas.

Republik Indonesia. 2003, Undang-undang nomor 20 tahun 2003, Tentang sistem pendidikan nasional. Jakarta: Depdiknas.

Republik Indonesia, 2010. Disain induk pendidikan karakter. Jakarta: Kemdiknas. 
Sudrajat, Akhmad. 2008. Prinsip pengembangan kurikulum. http://id.worpress. com/tag/artikel. [29 Julai 2010]

Setyosari Punaji. 2013. Metode Penelitian Pendidikan dan Pengembangan. Jakarta: Kencana Prenadamadia Group.

Silberman, M.L. (1996). Active Learning: 101 Strategies to Teach Any Subject. Boston: Allyn Bacon. 